ISSN: 2224-0616

Int. J . Agril. Res. Innov. \& Tech. 5(1): 10-14, J une, 2015

Available online at http:// www.ijarit.webs.com

\title{
SOIL PROPERTIES AND BIOLOGICAL ACTIVITY AS INFLUENCED BY NUTRIENT MANAGEMENT IN RICE- FALLOW SORGHUM
}

\author{
N. Goutami, P.P. Rani*, R.L. Pathy and P.R. Babu
}

Received 26 January 2015, Revised 13 March 2015, Accepted 26 June 2015, Published online 30 June 2015

\begin{abstract}
A field experiment was conducted to observe the effect of inorganics, bio-fertilizers and FYM applied to rice-fallow sorghum on soil properties and biological activity at Agricultural College Farm, Bapatla during 2012. Soil samples were collected at flowering and harvest of the crop and were analysed for bulk density (BD), porosity, $\mathrm{pH}$, electrical conductivity (EC), organic carbon, N, P, K and micronutrients by standard methods. Results indicated that the soil properties viz., bulk density, porosity, $\mathrm{pH}$ and EC were not markedly influenced by the imposed treatments, while significantly high organic carbon was recorded in FYM treated plots. There was a significant influence of the treatments on available nitrogen and phosphorus, but not on potassium. Among micronutrients ( $\mathrm{Cu}, \mathrm{Zn}, \mathrm{Mn}$ and $\mathrm{Fe}$ ), the treatmental influence was significantly related to $\mathrm{Fe}$ only. Addition of inorganics in combination with organics and bio-fertilizers proved to be more efficient in improving the microbial population and enzyme activities (urease and dehydrogenase) significantly.
\end{abstract}

Keywords: Organic Manure, Bio-fertilizers, Enzyme Activity, Microbial Population

Department of Soil Science and Agricultural Chemistry, Agricultural College, Bapatla-522 101, Hyderabad, India

*Corresponding author's email: pprasuna09@yahoo.com (P.P. Rani)

\section{Introduction}

Continuous adoption of rice - sorghum sequence is a point of concern as cultivation of two cereal crops in a year involves heavy removal of nutrients, which diminishes the soil health and in turn productivity. Adopting cereal-cereal sequence for longer periods with low system productivity, and often with poor crop management practices, results in loss of soil fertility due to emergence of multiple nutrient deficiency (Dwivedi et al., 2001) and deterioration of soil physical properties (Tripathi, 1992). It is therefore necessary to judiciously manage the inflow of nutrients by integration of all sources.

At this juncture conjunctive use of organics can increase the productivity of soils as they act as a source of nutrients and modify the soil physical behavior as well as increase the efficiency of applied nutrients (Sahadeva Reddy and Aruna, 2008). However, application of organics and biofertilizers to rice-fallows is uncommon due to the difficulty in their decomposition and use by the fallow crops. The present study was carried out to observe the influence of inorganics, bio-fertilizers and well-decomposed FYM applied to rice-fallow sorghum on soil properties and biological activity of soils.

\section{Materials and Methods}

A field experiment was conducted at the Agricultural College Farm, Bapatla of Acharya
N.G. Ranga Agricultural University in rice-fallow situation during 2012. The experiment was laid out in a randomized block design with three replications and thirteen treatments viz., $\mathrm{T}_{1}-90$ kg N ha-1; $\mathrm{T}_{2}-120 \mathrm{~kg} \mathrm{~N}^{-1}{ }^{-1} \mathrm{~T}_{3}-150 \mathrm{~kg} \mathrm{~N}^{-1}{ }^{-1} \mathrm{~T}_{4}$ - 90 kg N ha-1 + Bio-fertilizers; $\mathrm{T}_{5}-120 \mathrm{~kg} \mathrm{~N} \mathrm{ha}{ }^{-1}+$ Bio-fertilizers; $\mathrm{T}_{6}-150 \mathrm{~kg} \mathrm{~N}$ ha-1 + Bio-fertilizers; $\mathrm{T}_{7}$ - $90 \mathrm{~kg} \mathrm{Nha}{ }^{-1}+$ FYM; $_{8}-120 \mathrm{~kg} \mathrm{Nha}^{-1}+\mathrm{FYM}$ T9 - 150 kg N ha-1 + FYM; T10 - 90 kg N ha-1 + FYM + Bio-fertilizers; $\mathrm{T}_{11}-120 \mathrm{~kg} \mathrm{~N} \mathrm{ha}^{-1}+\mathrm{FYM}^{-}$ Bio-fertilizer; $\mathrm{T}_{12}$ - $150 \mathrm{~kg} \mathrm{~N}$ ha-1 + FYM + Biofertilizers; $\mathrm{T}_{13}$ - No nitrogen (Control). The soil of the experimental field was sandy clay loam in texture, neutral in reaction ( $\mathrm{pH}$ 7.4), medium in organic carbon (0.55\%), low in available nitrogen (122 kg ha-1), medium in available phosphorus (27.9 $\mathrm{kg} \mathrm{ha}^{-1}$ ) and high in available potassium (729 $\mathrm{kg} \mathrm{ha}^{-1}$ ). The counts of bacterial population obtained in the initial soil was $1.1 \times$ $10^{6} \mathrm{CFU} \mathrm{g}^{-1}$ soil, while the fungal population was $6 \times 10^{3} \mathrm{CFU} \mathrm{g}^{-1}$ soil. The urease activity in the soil was $9.4 \mu \mathrm{g} \mathrm{NH} 4^{+-} \mathrm{N} \mathrm{g}^{-1}$ soil $\mathrm{h}^{-1}$, while the dehydrogenase activity was $25.84 \mu \mathrm{g}$ TPF g-1 soil $24 \mathrm{~h}^{-1}$. Sorghum hybrid MLSH-151 was dibbled at $45 \mathrm{~cm} \times 15 \mathrm{~cm}$ spacing on 2nd February, 2012. Well decomposed ( $\mathrm{C}: \mathrm{N}$ of $25: 1) \mathrm{FYM}$ was applied 7 days before sowing. Bio-fertilizer consortium consisting of Azospirillum, phosphorus solubilising bacteria (PSB) and plant growth promoting rhizobacteria (PGPR) @5 kg ha $^{-1}$ each was applied one day before sowing. Nitrogen was applied in 2 splits, while $\mathrm{P}_{2} \mathrm{O}_{5}$ and 
$\mathrm{K}_{2} \mathrm{O}$ (30 kg ha-1 each) were applied to all treatments as per recommendation. Soil samples were collected at flowering and harvest of the crop and were analysed for bulk density (BD), porosity, $\mathrm{pH}$, electrical conductivity (EC), organic carbon, N, P, K and micronutrients by standard methods. The enumeration of total bacteria and fungi in fresh soil samples was carried out by following serial dilution plate count technique as given by Dhingra and Sinclair (2000) and Martin (1950), respectively. Urease activity was estimated by quantifying the rate of release of $\mathrm{NH}_{4}{ }^{+}$- $\mathrm{N}$ from the hydrolysis of urea as described by Tabatabai and Bremner (1972). Dehydrogenase activity in the soil sample was determined by following the procedure as described by Casida et al. (1964).

\section{Results and Discussion}

\section{Physico-chemical properties of soil}

Bulk density and porosity of the experimental soil were not influenced significantly by the imposed treatments (Table 1). However, the treatments supplied with FYM ( $T_{7}$ to $\left.T_{12}\right)$ recorded the lower bulk density and porosity values compared to other treatments. Similar findings were observed by Bellakini and Badanur (1997). Application of inorganics alone or in combination with bio-fertilizers and FYM did not show any significant effect on $\mathrm{pH}$ of the soil. The EC values of the soil were not significantly influenced by bio-fertilizers and FYM either alone or in combination at different levels of nitrogen. The increase in inorganic nitrogen level from 90 to $150 \mathrm{~kg} \mathrm{~N}^{-1}$ either alone or in combination with bio-fertilizer did not show any significant increase in organic carbon content. The treatments supplied with FYM recorded higher organic carbon than the treatments, which received inorganics alone, and in combination with bio-fertilizers. Improvement in organic carbon status with increasing level of fertilizer nitrogen from 90 to $150 \mathrm{~kg} \mathrm{~N}^{-1}$ over initial soil organic carbon content could be attributed to increased biomass production (root mass and root exudates) with increased level of fertilizer application. Similar findings were observed by Tolanur and Badanur (2003).

Table 1. Effect of nitrogen levels, bio-fertilizers and FYM on physico-chemical properties of soil at harvesting time

\begin{tabular}{|c|c|c|c|c|c|c|}
\hline Treatments & $\begin{array}{c}\mathrm{BD} \\
\left(\mathrm{Mgm}^{-3}\right)\end{array}$ & $\begin{array}{c}\mathrm{PD} \\
\left(\mathrm{Mg} \mathrm{m}^{-3}\right)\end{array}$ & $\begin{array}{c}\text { Porosity } \\
(\%)\end{array}$ & $\mathrm{pH}$ & $\begin{array}{c}\mathrm{EC} \\
\left(\mathrm{dSm}^{-1}\right) \\
\end{array}$ & $\begin{array}{c}\mathrm{OC} \\
\mathrm{g} \mathrm{kg}^{1}\end{array}$ \\
\hline $\mathrm{T}_{1}: 90 \mathrm{kgNha}^{-1}$ & 1.48 & 2.62 & 43.51 & 7.2 & 0.37 & 5.70 \\
\hline $\mathrm{T}_{2}: 120 \mathrm{kgN} \mathrm{ha}^{-1}$ & 1.46 & 2.63 & 44.48 & 7.3 & 0.36 & 5.75 \\
\hline $\mathrm{T}_{3}: 150 \mathrm{~kg} \mathrm{~N} \mathrm{ha}^{-1}$ & 1.47 & 2.62 & 44.52 & 7.1 & 0.35 & 5.82 \\
\hline $\mathrm{T}_{4}: 90 \mathrm{kgN} \mathrm{ha}^{-1}+$ Bio-fertilizers & 1.47 & 2.62 & 43.89 & 7.2 & 0.35 & 5.76 \\
\hline $\mathrm{T}_{5}: 120 \mathrm{~kg} \mathrm{~N} \mathrm{~h}^{-1}+$ Bio-fertilizers & 1.45 & 2.65 & 45.28 & 7.3 & 0.35 & 5.89 \\
\hline 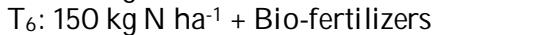 & 1.46 & 2.63 & 44.67 & 7.2 & 0.36 & 5.95 \\
\hline $\mathrm{T}_{7}: 90 \mathrm{kgN} \mathrm{ha}^{-1}+\mathrm{FYM}$ & 1.46 & 2.65 & 46.52 & 7.2 & 0.36 & 6.10 \\
\hline T8: $120 \mathrm{~kg} \mathrm{~N} \mathrm{ha}^{-1}+\mathrm{FYM}$ & 1.44 & 2.66 & 47.63 & 7.1 & 0.35 & 6.18 \\
\hline $\mathrm{T}_{9}: 150 \mathrm{kgN} \mathrm{ha}^{-1}+\mathrm{FYM}$ & 1.43 & 2.67 & 47.81 & 7.1 & 0.34 & 6.29 \\
\hline $\mathrm{T}_{10}: 90 \mathrm{~kg} \mathrm{Nha}^{-1}+\mathrm{FYM}+$ Bio-fertilizers & 1.43 & 2.65 & 48.02 & 7.1 & 0.34 & 6.14 \\
\hline T11: $120 \mathrm{kgN} \mathrm{ha}^{-1}+\mathrm{FYM}+$ Bio-fertilizers & 1.41 & 2.68 & 48.12 & 7.1 & 0.34 & 6.25 \\
\hline $\mathrm{T}_{12}: 150 \mathrm{~kg} \mathrm{~N} \mathrm{ha}^{-1}+\mathrm{FYM}+$ Bio-fertilizers & 1.42 & 2.69 & 48.72 & 7.2 & 0.34 & 6.35 \\
\hline $\mathrm{T}_{13:}$ No nitrogen (Control) & 1.49 & 2.61 & 42.91 & 7.2 & 0.38 & 5.30 \\
\hline SEm \pm & 0.01 & 0.02 & 2.14 & 0.10 & 0.01 & 0.16 \\
\hline $\mathrm{CD}(0.05 \%)$ & NS & NS & NS & NS & NS & 0.27 \\
\hline
\end{tabular}

Note: FYM @ 10 t ha $^{-1}$; Bio-fertilizer consortium consists of Azospirillum, PSB and PGPR @ $5 \mathrm{~kg} \mathrm{ha}^{-1}$ each.

\section{Soil available nutrients}

Macronutrients

Data pertaining to the available nitrogen content of the soils at flowering and harvest presented in table 2 revealed that there was an increase in available nitrogen content both at flowering and harvest of crop in all treatments except $\mathrm{T}_{13}$ (no nitrogen) over the initial soil status (122 $\left.\mathrm{kg} \mathrm{ha}^{-1}\right)$. Significant increase with increase in $\mathrm{N}$ dose was observed in the presence of bio-fertilizer consortium and / or FYM. However, at a given dose, addition of FYM alone and in combination with bio-fertilizer resulted in a significant increase in available nitrogen. The maximum available nitrogen contents both at flowering and harvest (197 and $176 \mathrm{~kg} \mathrm{ha}^{-1}$, respectively) were recorded with $\mathrm{T}_{12}$ (150 kg N ha-1 + FYM + Biofertilizers), while the lowest values (115 and $97 \mathrm{~kg}$ ha $^{-1}$, respectively) were recorded with treatment $\mathrm{T}_{13}$ (no nitrogen). The higher availability of nitrogen in soil by application of organic manures can be attributed to mineralization of organic forms of nitrogen from the manures. The high available nitrogen status at both stages in treatments integrated with other components might be ascribed to fixation of nitrogen by Azospirillum and additional supply of nitrogen through FYM compared to sole inorganic treatments. 
Table 2. Effect of nitrogen levels, bio- fertilizers and FYM on available macronutrients (kg ha-1) in soil

\begin{tabular}{|c|c|c|c|c|c|c|}
\hline \multirow{2}{*}{ Treatments } & \multicolumn{2}{|c|}{ Nitrogen } & \multicolumn{2}{|c|}{ Phosphorus } & \multicolumn{2}{|c|}{ Potassium } \\
\hline & Flowering & Harvest & Flowering & Harvest & Flowering & Harvest \\
\hline $\mathrm{T}_{1}-90 \mathrm{kgNha}^{-1}$ & 134 & 115 & 28.9 & 27.2 & 809 & 729 \\
\hline $\mathrm{T}_{2}-120 \mathrm{~kg} \mathrm{Nha}^{-1}$ & 156 & 135 & 32.9 & 31.7 & 817 & 735 \\
\hline $\mathrm{T}_{3}-150 \mathrm{~kg} \mathrm{~N} \mathrm{ha}^{-1}$ & 168 & 149 & 37.2 & 35.5 & 920 & 753 \\
\hline $\mathrm{T}_{4}-90 \mathrm{~kg} \mathrm{Nha}^{-1}+$ Bio-fertilizers & 137 & 119 & 30.4 & 28.4 & 893 & 745 \\
\hline $\mathrm{T}_{5}-120 \mathrm{~kg} \mathrm{~N} \mathrm{ha}^{-1}+$ Bio-fertilizers & 158 & 140 & 34.9 & 32.8 & 939 & 809 \\
\hline T6-150 kg N ha-1+Bio-fertilizers & 170 & 155 & 38.6 & 36.0 & 951 & 822 \\
\hline $\mathrm{T}_{7}-90 \mathrm{kgN} \mathrm{ha}^{-1}+\mathrm{FYM}$ & 160 & 145 & 35.4 & 33.7 & 815 & 730 \\
\hline $\mathrm{T}_{8}-120 \mathrm{~kg} \mathrm{~N} \mathrm{ha}^{-1}+\mathrm{FYM}$ & 179 & 161 & 39.4 & 37.9 & 870 & 745 \\
\hline $\mathrm{T}_{9}-150 \mathrm{~kg} \mathrm{Nha}^{-1}+\mathrm{FYM}$ & 194 & 174 & 43.9 & 41.5 & 928 & 756 \\
\hline $\mathrm{T}_{10}-90 \mathrm{~kg} \mathrm{~N}$ ha-1+FYM+Bio-fertilizers & 165 & 149 & 36.8 & 34.9 & 897 & 752 \\
\hline $\mathrm{T}_{11}-120 \mathrm{~kg} \mathrm{~N} \mathrm{ha}^{-1}+\mathrm{FYM}+$ Bio-fertilizers & 189 & 171 & 42.7 & 39.7 & 949 & 826 \\
\hline $\mathrm{T}_{12}-150 \mathrm{~kg} \mathrm{~N} \mathrm{ha}^{-1}+\mathrm{FYM}+\mathrm{Bio}-$ fertilizers & 197 & 176 & 44.9 & 42.7 & 974 & 842 \\
\hline $\mathrm{T}_{13}$-No Nitrogen & 115 & 97 & 24.5 & 23.5 & 745 & 717 \\
\hline SEm \pm & 6.12 & 5.18 & 1.35 & 1.19 & 29 & 17 \\
\hline $\mathrm{CD}(0.05 \%)$ & 18 & 15 & 3.9 & 3.5 & NS & NS \\
\hline
\end{tabular}

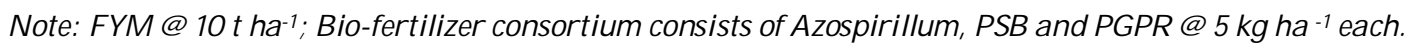

The availability of phosphorus increased significantly with increase in nitrogen dose up to $150 \mathrm{~kg} \mathrm{ha}^{-1}$ of nitrogen alone or in combination with FYM (Table 2). The availability of $\mathrm{P}$ significantly increased in bio- fertilizer treated plots only up to $120 \mathrm{~kg} \mathrm{~N}^{-1}$. The highest available phosphorus at flowering and harvest stages was observed in $\mathrm{T}_{12}\left(150 \mathrm{~kg} \mathrm{~N} \mathrm{Na}^{-1}+\mathrm{FYM}\right.$ + Bio- fertilizers), which was 60.93 and 53.04 per cent, respectively higher than initial available phosphorus status of soil. The lowest was observed in $\mathrm{T}_{13}$ (no nitrogen) at both stages. Available phosphorus content of the soil was higher in treatments receiving bio- fertilizers along with FYM than their individual application at different levels of nitrogen, which might be due to more effectiveness of bio-fertilizers in solubilizing the insoluble phosphorus in the presence of FYM, which acts as an immediate nutrient source for microbes.

The perusal of data presented in table 2 indicated that available potassium was not significantly influenced by different treatments at flowering and harvest. Maximum available $\mathrm{K}$ contents at flowering (974 kg ha-1) and harvest (842 kg ha-1) were observed in $\mathrm{T}_{12}$ (150 kg N ha-1 + FYM + Bio- fertilizers) and the lowest available $\mathrm{K}$ content at flowering (745 kg ha-1) and at harvest (717 kg ha1) were recorded in $T_{13}$

\section{Micronutrients}

The data related to DTPA extractable copper, zinc, manganese and iron contents are presented in the tables 3. Available copper, zinc and manganese were not significantly influenced by different treatments at both flowering and harvest stages of the crop. Maximum available nutrient contents at flowering and harvest were observed in $\mathrm{T}_{12}$ (150 kg N ha-1 + FYM + Biofertilizers) and the lowest available nutrient contents at flowering and harvest were recorded in $\mathrm{T}_{13}$. The zinc contents were above the critical limit of $0.8 \mathrm{mg} \mathrm{kg}^{-1}$ (Lindsey and Norvell, 1978) in FYM treated plots with higher doses of $\mathrm{N}$ at flowering indicating that crop was well supplied with zinc during peak grain filling stage. The availability of iron increased significantly with increase in nitrogen dose up to $120 \mathrm{~kg} \mathrm{ha}^{-1}$ of nitrogen with bio-fertilizers or FYM or their combination.

Table 3. Effect of nitrogen levels, bio-fertilizers and FYM on available micronutrients $\left(\mathrm{mg} \mathrm{kg}^{1}\right)$ in soils

\begin{tabular}{|c|c|c|c|c|c|c|c|c|}
\hline \multirow{2}{*}{ Treatments } & \multicolumn{2}{|c|}{ Copper } & \multicolumn{2}{|c|}{ Zinc } & \multicolumn{2}{|c|}{ Manganese } & \multicolumn{2}{|c|}{ Iron } \\
\hline & Flowering & Harvest & Flowering & Harvest & Flowering & Harvest & Flowering & Harvest \\
\hline $\mathrm{T}_{1}-90 \mathrm{~kg} \mathrm{Nha}^{-1}$ & 4.13 & 3.45 & 0.48 & 0.42 & 7.88 & 6.63 & 9.27 & 7.86 \\
\hline $\mathrm{T}_{2}-120 \mathrm{~kg} \mathrm{Nha}^{-1}$ & 4.28 & 3.53 & 0.61 & 0.49 & 7.98 & 6.7 & 10.56 & 9.10 \\
\hline $\mathrm{T}_{3}-150 \mathrm{kgN} \mathrm{ha}^{-1}$ & 4.51 & 3.62 & 0.74 & 0.62 & 8.24 & 6.79 & 11.42 & 9.86 \\
\hline $\mathrm{T}_{4}-90 \mathrm{~kg} \mathrm{Nha}^{-1}+$ Bio-fertilizers & 4.14 & 3.49 & 0.5 & 0.42 & 7.91 & 6.65 & 9.41 & 7.95 \\
\hline $\mathrm{T}_{5}-120 \mathrm{~kg} \mathrm{~N} \mathrm{~h}^{-1}+$ Bio-fertilizers & 4.31 & 3.56 & 0.61 & 0.52 & 8.1 & 6.72 & 10.74 & 9.26 \\
\hline $\mathrm{T}_{6}-150 \mathrm{~kg} \mathrm{~N} \mathrm{ha}^{-1}+$ Bio-fertilizers & 4.55 & 3.6 & 0.76 & 0.64 & 8.32 & 6.82 & 11.55 & 9.95 \\
\hline $\mathrm{T}_{7-90} \mathrm{~kg} \mathrm{~N} \mathrm{ha}^{-1}+\mathrm{FYM}$ & 4.32 & 3.58 & 0.62 & 0.58 & 8.12 & 6.74 & 10.94 & 9.47 \\
\hline $\mathrm{T}_{8}-120 \mathrm{~kg} \mathrm{~N} \mathrm{ha}{ }^{-1}+\mathrm{FYM}$ & 4.75 & 3.64 & 0.85 & 0.65 & 8.49 & 6.84 & 12.40 & 10.80 \\
\hline $\mathrm{T}_{9}-150 \mathrm{~kg} \mathrm{~N} \mathrm{ha}^{-1}+\mathrm{FYM}$ & 4.74 & 3.67 & 0.93 & 0.68 & 8.69 & 6.92 & 12.90 & 11.40 \\
\hline $\mathrm{T}_{10}-90 \mathrm{kgN} \mathrm{ha}^{-1}+\mathrm{FYM}+$ Bio-fert. & 4.35 & 3.60 & 0.63 & 0.60 & 8.13 & 6.77 & 11.28 & 9.74 \\
\hline $\mathrm{T}_{11}-120 \mathrm{~kg} \mathrm{~N}$ ha-1+FYM+Bio-fert. & 4.71 & 3.65 & 0.91 & 0.67 & 8.43 & 6.96 & 12.70 & 11.10 \\
\hline $\mathrm{T}_{12}-150 \mathrm{~kg} \mathrm{~N} \mathrm{ha}^{-1}+\mathrm{FYM}+$ Bio-fert. & 4.87 & 3.68 & 0.94 & 0.69 & 8.54 & 6.98 & 13.20 & 12.00 \\
\hline T13-No Nitrogen & 3.93 & 3.39 & 0.37 & 0.41 & 7.76 & 6.61 & 7.86 & 6.74 \\
\hline SEm \pm & 0.10 & 0.07 & 0.05 & 0.07 & 0.23 & 0.17 & 0.42 & 0.39 \\
\hline $\mathrm{CD}(0.05 \%)$ & NS & NS & NS & NS & NS & NS & 1.15 & 1.11 \\
\hline
\end{tabular}

FYM @ 10 t ha- $^{-1}$; Bio-fertilizer consortium consists of Azospirillum, PSB and PGPR @ 5 kg ha -1 each. 
The increase in available micronutrients status of soils in organically treated plots might be due to addition of micronutrients through FYM and release of chelating agents from organic matter decomposition, which might have prevented micronutrients from precipitation, oxidation and leaching (Sharma et al., 2001). Reduction in micronutrient contents in inorganic treatments can be attributed to non-replenishment of micronutrients through chemical fertilizers.

\section{Biological activity}

Microbial population

Application of inorganic treatments alone or in combination with bio-fertilizers and FYM showed significant effect on bacterial population up to $120 \mathrm{~kg} \mathrm{~N} \mathrm{ha}^{-1}$. At a given dose of nitrogen the treatments received FYM were significantly superior over treatment that received inorganics or in combination with bio-fertilizers. The maximum bacterial and fungal population was noticed in the treatment $T_{12}\left(10.6 \times 10^{6}, 5 \times 10^{4}\right.$ CFU $\mathrm{g}^{1}$ soil, respectively) while the minimum population was recorded in treatment $\mathrm{T}_{13}(3.1 \mathrm{X}$ $10^{6}, 1.1 \times 10^{4} \mathrm{CFU} \mathrm{g}{ }^{-1}$ soil, respectively). The increase in microbial population with the incorporation of organics (FYM) might be due to the improvement of hydrothermal regime and supply of large amount of carbon, a major food source for several bacteria and all fungi involved in decomposition. High bacterial population as compared to fungi may be due to their short generation time and high multiplication rate. The results are in agreement with the findings of Ghate et al. (1994).

\section{Enzyme activity}

Data presented in the table 4 indicated that urease activity of the soils at flowering and harvest of crop was significantly influenced by different treatments.

Table 4. Effect of nitrogen levels, bio-fertilizers and FYM on biological activity in soils

\begin{tabular}{|c|c|c|c|c|c|c|}
\hline \multirow{2}{*}{ Treatments } & \multicolumn{2}{|c|}{ Urease activity } & \multicolumn{2}{|c|}{ Dehydrogenase activity } & \multicolumn{2}{|c|}{ Microbial population } \\
\hline & Flowering & Harvest & Flowering & Harvest & Bacteria $\left(\mathrm{x} 10^{6}\right)$ & Fungi (x104) \\
\hline $\mathrm{T}_{1}-90 \mathrm{kgN} \mathrm{ha}^{-1}$ & 14.1 & 11.5 & 60.29 & 39.87 & 4.6 & 1.7 \\
\hline $\mathrm{T}_{2}-120 \mathrm{~kg} \mathrm{~N} \mathrm{ha}^{-1}$ & 17.1 & 13.8 & 64.06 & 42.89 & 6.0 & 2.3 \\
\hline $\mathrm{T}_{3}-150 \mathrm{~kg} \mathrm{~N} \mathrm{ha}^{-1}$ & 19.8 & 15.4 & 68.08 & 45.29 & 6.5 & 2.6 \\
\hline $\mathrm{T}_{4}-90 \mathrm{kgN} \mathrm{ha}^{-1}+\mathrm{Bio}$-fertilizers & 15.7 & 11.9 & 60.84 & 40.09 & 5.9 & 2.3 \\
\hline $\mathrm{T}_{5}-120 \mathrm{~kg} \mathrm{~N} \mathrm{ha}^{-1}+\mathrm{Bio}-$ fertilizers & 18.4 & 14.1 & 64.37 & 43.92 & 7.2 & 2.9 \\
\hline $\mathrm{T}_{6}-150 \mathrm{~kg} \mathrm{~N} \mathrm{ha}^{-1}+$ Bio-fertilizers & 21.2 & 16.9 & 69.28 & 46.62 & 7.7 & 3.1 \\
\hline $\mathrm{T}_{7-90} \mathrm{kgN} \mathrm{ha}^{-1}+\mathrm{FYM}$ & 17.2 & 13.3 & 63.04 & 40.04 & 7.5 & 3.4 \\
\hline $\mathrm{T}_{8}-120 \mathrm{kgN} \mathrm{ha}^{-1}+\mathrm{FYM}$ & 19.9 & 15.5 & 66.49 & 43.44 & 8.8 & 4.4 \\
\hline T9-150 kg N ha-1+FYM & 23.8 & 17.1 & 71.42 & 47.24 & 9.2 & 4.8 \\
\hline $\mathrm{T}_{10}-90 \mathrm{~kg} \mathrm{Nha}^{-1}+\mathrm{FYM}+$ Bio-fert. & 20.5 & 14.8 & 63.42 & 42.47 & 8.5 & 4.2 \\
\hline $\mathrm{T}_{11}-120 \mathrm{kgN} \mathrm{ha}^{-1}+\mathrm{FYM}+$ Bio-fert. & 23.3 & 16.9 & 67.24 & 45.04 & 9.6 & 4.6 \\
\hline T12-150 kg N ha-1+FYM+Bio-fert. & 26.1 & 18.5 & 72.89 & 49.78 & 10.6 & 5.0 \\
\hline $\mathrm{T}_{13}$-No Nitrogen & 11.3 & 9.2 & 57.08 & 37.89 & 3.1 & 1.1 \\
\hline SEm \pm & 0.87 & 0.61 & 0.85 & 0.56 & 0.44 & 0.16 \\
\hline $\mathrm{CD}(0.05 \%)$ & 2.6 & 1.5 & 2.08 & 1.35 & 1.2 & 0.5 \\
\hline
\end{tabular}

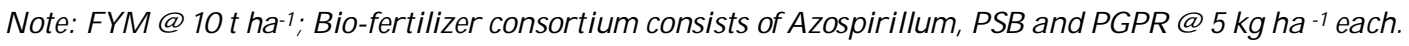

There was a significant increase in urease activity with increase in nitrogen up to $150 \mathrm{~kg} \mathrm{~N}^{-1} \mathrm{a}^{-1}$ both at flowering (14.1 to $19.8 \mu \mathrm{g} \mathrm{NH}_{4}^{+}-\mathrm{N} \mathrm{g}^{-1}$ soil h-1) and harvest (11.5 to $15.4 \mu \mathrm{g} \mathrm{NH}_{4}{ }^{+}-\mathrm{N} \mathrm{g}^{1}$ soil $\mathrm{h}^{-1}$ ). Bio-fertilizers when combined with different levels of nitrogen, resulted in significant increase in urease activity. Among FYM treated plots, The urease activity at flowering stage $\left(26.10 \mathrm{gg} \mathrm{NH}_{4}{ }^{+}\right.$ - $\mathrm{N} \mathrm{g}^{-1}$ soil h-1) and at harvest (18.5 $\mu \mathrm{g} \mathrm{NH}_{4}{ }^{+}-\mathrm{N}$ $\mathrm{g}^{-1}$ soil $\mathrm{h}^{-1}$ ) were highest when the treatment received combined application of $150 \mathrm{~kg} \mathrm{~N}^{-1}+$ FYM + Bio- fertilizer $\left(T_{12}\right)$, which was on par with $\mathrm{T}_{9}$. The lowest enzyme activity was observed in $\mathrm{T}_{13}$ treatment (no nitrogen). Enhancement of urease activity with increased rate of nitrogen application along with FYM to soil might be due to added organic manures which acted as sole source of carbon and energy for microbes by which their population increased resulting in increased enzymatic activity (Quireshi et al.,1995). There was a significant increase in dehydrogenase activity with increase in nitrogen up to $150 \mathrm{~kg} \mathrm{~N} \mathrm{ha}^{-1}$ in all combinations. Among FYM treated plots the dehydrogenase activities at flowering (72.89 $\mathrm{\mu g} \mathrm{g}^{1} 24 \mathrm{~h}^{-1}$ ) and harvest (49.78 $\mathrm{ug} \mathrm{g}^{-1} 24 \mathrm{~h}^{-1}$ ) were highest when the treatment received combined application of 150 $\mathrm{kg} \mathrm{N} \mathrm{ha-1}+\mathrm{FYM}+$ Bio fertilizers $\left(\mathrm{T}_{12}\right)$, which were on par with $T_{9}$ and $T_{11}$, respectively. The lowest enzyme activity was observed in $\mathrm{T}_{13}$ treatment (no nitrogen). The soil dehydrogenase activity increased with addition of organic carbon through FYM. The enzyme activity was maximum at flowering compared to harvest. This could be due to higher root exudates from the plant roots at flowering over harvesting stage (Vancura et al., 1977; Hale et al., 1978). The increase in dehydrogenase activity in FYM treated plots could also be attributed to increase in microbial population. 


\section{References}

Bellakini, M.A. and Badanur, V.P. 1997. Longterm effect of integrated nutrient management on properties of Vertisol under dry land agriculture. J. Indian Soc. Soil Sci. 45: 438-442.

Casida, L., Klein, D. and Santoro, T. 1964. Soil dehydrogenase activity. Soil Sci.98: 371-376.

Dhingra, O.D. and Sinclair, J.B. 2000. Basic plant pathology methods. CEC press, London. pp. 122-125.

Dwivedi, B.S., Shukla, A.K., Singh, V.K. and Yadav, R.L. 2001. Development of farmers' resource-based integrated plant nutrient supply systems. IISS, Bhopal, India. pp. 5075.

Ghate, R.M., Rawankar, H.N., Kavita More and Jaya Miranjane. 1994. Residual effect of wheat straw and fertilizer applied to kharif mung on soil microbial population. Madras Agril. J. 81: 231-233.

Hale, H.G., Moore, L.D. and Griffin, C.J. 1978. Root exudates and exudation. In: interactions between non - pathogenic soil microorganisms and plants, Elsevier Scientific Publishing, New York. pp. 163203.

Lindsey, W.L. and Norvell, W.A. 1978. Development of DTPA soil test for zinc, iron, manganese and copper. Soil Sci. Soc. America J. 41: 421-428.

Martin, J.P. 1950. Use of acid rose Bengal and streptomycin in the plate method for estimating soil fungi. Soil Sci. 69: 215-232.
Quireshi, A., Patil, C.V. and Prakash, S.S. 1995. Crop residue management for sustainable agriculture. Paper presented in Int. Conf. on Sustainable Agric. Env. HAU, Hissar. 63p.

Sahadeva Reddy, B. and Aruna, E. 2008. Integrated nutrient management in hybrid sorghum. J . Cotton Res. \& Dev. 22 (2): 153156.

Sharma, M.P., Balf, S.V. and Gupta, D.K. 2001. Soil fertility and productivity of rice (Oryza sativa)-wheat (Triticum aestivum) cropping system in an Inceptisol as influenced by Integrated Management. Indian J. Agril. Sci. 71: 81-86.

Tabatabai, M.A. and Bremner, J.M. 1972. Assay of urease activity in soils. Soil Biol. \& Biochem. 4: 479-487.

Tolanur, S.I. and Badanur, V.P. 2003. Changes in organic carbon, available N, P and $\mathrm{K}$ under integrated use of organic manure, green manure and fertilizer on sustaining productivity of pearl millet-pigeon pea system and fertility of an Inceptisol. J. Indian Soc. Soil Sci. 5 (1): 37-41.

Tripathi, R.P. 1992. Physical properties and tillage of rice soils in rice- wheat system. PDCSR, Modipuram, India. pp. 53-67.

Vancura, V., Prikryl, Z, Kalachova, L. and Wurst, M. 1977. Some quantitative aspects of root exudation. Ecol. Bull. 25: 381-386. 